\title{
Factors governing soil water repellency under tillage management: The role of pore structure and hydrophobic substances
}

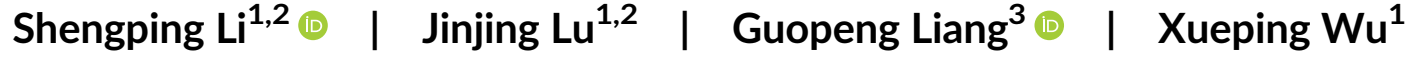 \\ Mengni Zhang ${ }^{1,2}$ | Erwan Plougonven ${ }^{4}$ ( ) Yunfei Wang ${ }^{5}$ | Lili Gao ${ }^{1}$ | \\ Ahmed Ali Abdelrhman $^{1}$ | Xiaojun Song ${ }^{1}$ | Xiaotong Liu ${ }^{1}$ | Aurore Degré ${ }^{2}$
}

${ }^{1}$ Institute of Agricultural Resources and Regional Planning, Chinese Academy of Agricultural Sciences, Beijing, PR China

${ }^{2} \mathrm{G} x \mathrm{ABT}$, Terra Research Center, University de Liège, Gembloux, Belgium

${ }^{3}$ Department of Biology, Utah State

University, Logan, Utah

${ }^{4}$ Department of Applied Chemistry, Laboratory of Chemical Engineering, University de Liège, Liège, Belgium

${ }^{5}$ Institute of Water Saving Agriculture in Arid Regions of China (IWSA), Northwest A \& F

University, Yangling, PR China

\section{Correspondence}

Xueping Wu, Institute of Agricultural Resources and Regional Planning, Chinese Academy of Agricultural Sciences, PR China.

Email: wuxueping@caas.cn

Aurore Degré, University de Liège, GxABT, Terra Research Centre, No. 2 Passage des Déportés, Gembloux 5030, Belgium.

Email: aurore.degre@uliege.be

Funding information

National Key Research and Development Program of China, Grant/Award Number: 2018YFE0112300; National Key Research Development Program of China, Grant/Award Number: 2018YFD0200408; National Science and Technology Project of China, Grant/Award Number: 2015BAD22B03

\begin{abstract}
Soil water repellency (SWR) has significant effects on soil degradation by changing some soil processes (e.g., carbon sequestration and soil erosion). Understanding the influence factors of SWR under conservation agriculture are playing a vital role in the sustainable development for improving soil quality. However, how soil pore structure influence on SWR remains unclear. We aim to assess the impact of hydrophobic substances and pore structure on SWR. Here we conducted two long-term experimental fields with three treatments: conventional tillage (CT), reduced tillage (RT), and notillage (NT). X-ray tomography and the sorptivity method were used to measure soil pore structure and SWR, respectively. We found that soil organic carbon $(\mathrm{SOC})$ and microbial biomass carbon (MBC) were higher in RT and NT treatments than in CT. MBC had significant influences on soil water sorptivity $\left(S_{w}\right)$ and water repellency index (RI; $p<0.001)$, whereas SOC had no influence on $S_{w}(p>0.05)$. MBC also showed a closer relationship with SWR than SOC in redundancy analysis. The RT and NT increased the porosity of 55-165 $\mu \mathrm{m}$ that had a positive relationship with ethanol sorptivity and $\mathrm{RI}(p<0.05)$. Ethanol sorptivity increased with an increase in soil pore porosity and connectivity under RT and NT treatments. However, increasing the pore surface area could decrease $S_{w}$ due to enhance contact area between hydrophobic substances and soil water. Overall, the RT and NT treatments increased the water repellency index, which was a result of the interactions between pore structure and hydrophobic substances.
\end{abstract}

KEYWORDS

conservation tillage, soil carbon, soil pore structure, soil water repellency, X-ray computed tomography

\section{1 | INTRODUCTION}

Soil water repellency (SWR) is a common phenomenon in coarse- to fine-textured soils across all climatic zones (Daniel, Uddin, Harper, \& Henry, 2019). SWR can limit the soil water absorption rate and capacity (Dekker \& Jungerius, 2000; Li, Yao, Tang, Chau, \& Feng, 2019), resulting in strong influences on the soil degradation and crop growth (González-Peñaloza et al., 2012; Martínez-garcía, Korthals, Brussaard, Bracht, \& De, 2018). A lot of research has already been conducted to reveal the impact of SWR on the soil ecosystem 
under forest and fire-affected soils (Debano, 2000; Plaza-Álvarez et al., 2018; Weninger, Filipovi, Me, Clothier, \& Filipovi, 2019). However, because the degree of SWR in farmland tillage soil is smaller than the forest and fire-affected soils (Lucas-Borja et al., 2019; Stavi, Barkai, Knoll, \& Zaady, 2016), there is a lack of research on the SWR in farmland, especially for the study on how conservation agriculture affect SWR. The small degree of SWR, known as subcritical water repellency (Hallett, Baumgartl, \& Young, 2001), can also have a considerable effect on soil structure and hydraulic properties (Hunter, Chau, \& Si, 2011; Tadayonnejad, Mosaddeghi, \& Ghorbani, 2017). Therefore, understanding the factors that affect SWR is critically important in improving soil quality.

SWR is considered to be created by hydrophobic organic compounds covering the surfaces of soil particles (Doerr, Shakesby, \& Walsh, 2000). These organic materials are produced by plant roots, leaves, and microorganisms (Fontaine, Mariotti, \& Abbadie, 2003; Seaton et al., 2019), which are the main sources of SOC (Schmidt et al., 2011; Stockmann et al., 2013). Some researchers have used SOC, as hydrophobic substances, to build relationships with SWR (Blanco-Canqui \& Lal, 2009; Zheng, Morris, Lehmann, \& Rillig, 2016). However, the results are contradictory. There have been reports of positive (Jimenez-Morillo et al., 2016; Zavala, González, \& Jordán, 2009), negative (Mataix-Solera et al., 2014), and no (Woche et al., 2005) relationships between SWR and SOC. These inconsistent results indicate that not all organic materials induce SWR. Research should focus on specific groups of compounds (Atanassova \& Doerr, 2011; Daniel et al., 2019). Microbial biomass carbon (MBC) can have a more useful and sensitive response to soil processes than the SOC (Sparling, 1992). It has been previously shown that there is a positive correlation between SWR and soluble carbohydrates linked to biological activity in soil (Behrends et al., 2019; Wander, 2004). Seaton et al. (2019) also found that soil microbial community composition strongly influenced SWR that could be induced by microbes in a shorter time. Therefore, studies should focus on identifying an accessible and reliable indicator for hydrophobic substances that more closely reflects SWR in order to overcome the inconsistent effects of SOC on SWR.

Another possible reason for the inconsistency between SWR and SOC is that SWR is affected by factors other than hydrophobic substances. SWR is described as soil water behavior on the soil surface that limits the rate and capacity for soil water absorption (Daniel et al., 2019). The factors that influence the SWR effects on soil function and crop growth, such as water infiltration (Madsen et al., 2011; Rye \& Smettem, 2017), plant available water (González-Peñaloza et al., 2012; Ritsema et al., 2008), and aggregate stability (Girona-García, Ortiz-Perpiná, Badía-Villas, \& Martí-Dalmau, 2018), are affected by soil water movement that usually occurs as unsaturated flow in a farmland environment (Han \& Zhou, 2018). Furthermore, the soil pore structure has been shown to be the main controlling soil water movement (Katuwal et al., 2015; Pagliai, Vignozzi, \& Pellegrini, 2004; Pituello, Dal Ferro, Simonetti, Berti, \& Morari, 2016), and therefore, SWR behavior could also be influenced by pore structure. For example, an increase in soil porosity or pore surface area could increase the possibility of contact between soil water and hydrophobic substances, which would increase SWR because it is controlled by hydrophobic substances on the surfaces of aggregates (Urbanek, Hallett, Feeney, \& Horn, 2007). In addition, the porosity of same sized pores has different impacts on hydraulic conductivity under different degrees of SWR (Nyman, Sheridan, \& Lane, 2010), which suggests that SWR behaviour can be influenced by pore-size distribution. Behrends et al. (2019) used the water drop penetration time (WDPT) method to establish that the time needed for a single water drop to infiltrate a soil sample, which shows the degree of SWR, was controlled by pore structure as well as hydrophobic substances.

Although soil pore structure is critical to understanding SWR, few studies, as far as we can ascertain, investigated how the pore network influences SWR using direct measurements. In addition to the limited theoretical knowledge about the relationship between pore structure and SWR, the main reason why there have been few studies on the pore network influences on SWR is that the soil pore structure is complicated and difficult to measure. In recent years, X-ray computed tomography $(\mu \mathrm{CT})$ has been successfully used to obtain a nondestructive and detailed 3D characterization of the soil porous system (Beckers et al., 2014; Young, Crawford, \& Rappoldt, 2001). Morphological variables, such as pore size, volume, shape, connectivity, and critical pore diameter can be obtained using $\mu \mathrm{CT}$ (Koestel \& Schlüter, 2019; Lu, Yu, \& Zong, 2019). Percolation theory, which states that flow takes place through a percolating pore network composed of multiple connected pathways (Renard \& Allard, 2013; Skaggs, 2006), is usually used to calculate some of these variables. In addition, critical path analysis, which is based on the theory, can be used to show that flow is limited in porous media by the smallest or bottleneck pore sizes. Initially, the theory was successfully used to calculate the permeability of rocks and artificial porous materials (Arns, Knackstedt, \& Martys, 2005; Ghanbarian, Torres-Verdín, \& Skaggs, 2016; Nokken \& Hooton, 2008). Jarvis, Larsbo, and Koestel (2017) further used X-ray computed tomography to show that percolation theory could describe the connectivity of pore structure in tilled soil. The critical pore diameter was the dominant factor controlling saturated hydraulic conductivity according to percolation theory and critical path analysis results (Koestel, Dathe, Skaggs, \& Klakegg, 2018).

Furthermore, most land-use types have a significant effect on soil pore structure (Fang et al., 2019; Palm, Blanco-Canqui, DeClerck, Gatere, \& Grace, 2014; Rabot, Wiesmeier, Schlüter, \& Vogel, 2018). The addition of crop residues combined with tillage management, which is one of the main conservation tillage methods, has been widely promoted and developed around the world as a way of sustainably increasing productivity by improving soil pore structure (Blanco-Canqui \& Ruis, 2018; Gao et al., 2019; Pittelkow et al., 2015). The addition of crop residues has two opposite impacts on SWR. It increases SWR because crop residues produce hydrophobic substances, but it reduces SWR by enhancing soil porosity and connectivity (Cosentino, Hallett, Michel, \& Chenu, 2010). Most researchers studied the effect of hydrophobic substances on SWR and they found the degree of SWR could increase with an increase in hydrophobic 
substances under conservation tillage practices (Blanco-Canqui, 2011 Miller et al., 2019; Roper, Ward, Keulen, \& Hill, 2013), whereas only a few researchers used indirect methods to measure soil pore structure and thereby assess the impact of pore structure on SWR. Hallett et al. (2001) and Cosentino et al. (2010) found that SWR was mainly controlled by hydrophobic compounds rather than pore structure when they used ethanol sorptivity as an indirect indicator of pore structure. However, other researchers have reported that SWR, when measured by the WDPT method, was more affected by pore structure than hydrophobicity (Behrends et al., 2019). However, these conclusions were not based on the direct measurement of pore structure and their results were only obtained from indirect indicators associated with pore structure. Although many researchers have noted the importance of pore structure, the real relationship between pore structure and SWR cannot be evaluated clearly.

In our study, two long-term experimental fields were conducted to fill the knowledge gap that few studies assessed the effect of soil pore structure on SWR using a direct method. We hypothesize that conservation tillage practices can reduce the degree of SWR by improving soil pore structure. The objectives were to (a) determine the effect of conservation tillage on SWR, soil pore structure, SOC, and MBC; and (b) understand how soil pore structure and hydrophobic substances change SWR. It is essential for better understand the role of conservation tillage practices on soil quality studying the effect of conservation tillage on SWR when both hydrophobic substances and pore structure were taken into account at the same time.

\section{2 | MATERIALS AND METHODS}

\subsection{Study site}

The study involved two long-term experimental locations at two Dryland Farming Experimental Stations to increase the credibility of our findings and provide a better understanding of how soil pore structure and hydrophobic substances affect SWR under conservation tillage practices. One experiment was located at Shouyang, Shanxi Province, Northern China (S) and the other was at Gongzhuling, Jilin Province, Northeast China (G). Table 1 shows some of the physical and chemical properties of the two soils at the beginning of the experiments.

The Shouyang experiment was set up in 2003 and the site has a continental monsoon climate with an average annual precipitation of $483 \mathrm{~mm}$ (Wang et al., 2019). The annual frost-free period is approximately 130 days, the experimental site has a sandy loam soil, and the annual average temperature is $7.4^{\circ} \mathrm{C}$.
The Gongzhuling experiment was established in 2015 and it has a continental monsoon climate. The annual frost-free period is 144 days. The experimental site has a clay loam soil and the average temperature is $5.6^{\circ} \mathrm{C}$. The average annual precipitation is $595 \mathrm{~mm}$ and $70 \%$ of the rainfall occurs between June and August (Zhang, Wang, Liu, Liu, \& Zhou, 2016).

\subsection{Experimental design}

The two long-term tillage experiments had a randomized complete block design. A total of 12 blocks ( 3 treatments $\times 4$ replications) was carried out in each experimental location. Each plot at Shouyang and Gongzhuling was $5 \mathrm{~m} \times 5 \mathrm{~m}$ and $12 \mathrm{~m} \times 30 \mathrm{~m}$ in size, respectively. The crop in the two experiments was rain-fed continuous spring maize. The fallow periods were from November to the following March in Shouyang and November to the following April in Gongzhuling. There were three treatments at both sites: (a) CT: conventional tillage with maize stalk removed after harvesting, plowing twice to about $30 \mathrm{~cm}$ depth with a moldboard plow after harvesting and before seeding (in April and May for Shouyang and Gongzhuling, respectively); (b) RT: reduced tillage with maize straw and fertilizers incorporated after harvesting (in October), plowing once to about $25 \mathrm{~cm}$ depth with a moldboard plow; and (c) NT: no-tillage with the maize stalk mulched after harvesting, then seeding and fertilizing with a no-till planter in the following April in Shouyang and May in Gongzhuling. Urea and calcium superphosphate fertilizers were applied to each plot in Shouyang at $105 \mathrm{~kg} \mathrm{~N} \mathrm{ha}^{-1}$ and $105 \mathrm{~kg} \mathrm{P}_{2} \mathrm{O}_{5}$ $\mathrm{ha}^{-1}$, respectively. Each plot in Gongzhuling, received $80 \mathrm{~kg} \mathrm{~N} \mathrm{ha}^{-1}$, $60 \mathrm{~kg} \mathrm{P}_{2} \mathrm{O}_{5} \mathrm{ha}^{-1}$, and $45 \mathrm{~kg} \mathrm{~K} \mathrm{ha}^{-1}$ as urea, calcium superphosphate, and potassium sulfate, respectively.

\section{3 | Soil sampling}

Samples from Shouyang and Gongzhuling were taken on September 10, 2018 and August 20, 2018, respectively. The soil sampling methods for the two sites were identical. Undisturbed core samples from the 0 to $10 \mathrm{~cm}$ layer were taken using steel rings (internal diameter: $4.9 \mathrm{~cm}$ and height: $5.0 \mathrm{~cm}$ ). The samples were used to determine SWR. Another set of undisturbed core samples were also taken using PVC tubes (internal diameter: $4.0 \mathrm{~cm}$ and height: $5.0 \mathrm{~cm}$ ) from the 0 to $10 \mathrm{~cm}$ layer to determine soil pore structure using X-ray computed tomography. All the undisturbed core samples were stored at $4^{\circ} \mathrm{C}$ in order to avoid damaging the soil pore structure and to minimize

TAB LE 1 Soil physical and chemical properties of the 0-10 cm layer for Shouyang Station in 2003 and for Gongzhuling Station in 2015

\begin{tabular}{|c|c|c|c|c|c|c|c|c|}
\hline \multirow[b]{2}{*}{ Location } & \multicolumn{3}{|c|}{ Soil particle-size distribution (\%) } & \multicolumn{3}{|c|}{ Available soil nutrient $\left(\mathrm{mg} \mathrm{kg}^{-1}\right)$} & \multirow[b]{2}{*}{$\operatorname{soc}\left(\mathrm{g} \mathrm{kg}^{-1}\right)$} & \multirow[b]{2}{*}{ Bulk density $\left(\mathrm{g} \mathrm{cm}^{-3}\right)$} \\
\hline & $20-200 \mu \mathrm{m}$ & $2-20 \mu \mathrm{m}$ & $<2 \mu \mathrm{m}$ & $\mathbf{N}$ & $\mathbf{P}$ & $\mathbf{K}$ & & \\
\hline Shouyang & 55.3 & 37.9 & 6.8 & 55 & 7.6 & 95 & 25.7 & 1.13 \\
\hline Gongzhuling & 40.0 & 23.9 & 36.1 & 67 & 12.4 & 97 & 22.6 & 1.24 \\
\hline
\end{tabular}


microbial development. Disturbed samples were collected using a hand auger with a $5 \mathrm{~cm}$ internal diameter and were used to measure soil organic carbon (SOC) and MBC. A total of 48 undisturbed core samples ( 2 fields $\times 2$ variables $\times 3$ treatments $\times 4$ replications) and 48 disturbed samples ( 2 fields $\times 2$ variables $\times 3$ treatments $\times 4$ replications) were taken.

\subsection{Soil analysis}

\subsection{1 | SWR characteristics}

The undisturbed soil core samples were air-dried for 2 weeks and then a tension micro infiltrometer was used to measure SWR according to the intrinsic sorptivity method (Hallett \& Young, 1999). The infiltrometer equipment consisted of a tube with one end connected to the liquid reservoir and the other end (with a $2 \mathrm{~mm}$ radius) was covered with a sponge. Detailed information about the equipment can be obtained from Hallett and Young (1999). The liquid reservoir was placed on an automatic counting electronic balance (0.001 g) which recorded the weight every $10 \mathrm{~s}$. Two liquids were used in our study: distilled water and ethanol $(95 \% \mathrm{v} / \mathrm{v})$. Detailed descriptions of the test methods can be found in Tadayonnejad et al. (2017). The pressure heads of the two liquids were the same in the tip covered with the sponge, which was touching the soil core sample surface. The pressure head was negative pressure to avoid saturated flow. The pressure head $(P)$ was calculated using the following equation (Tillman, Scotter, Wallis, \& Clothier, 1989):

$$
P=\frac{\rho g h}{\sigma}
$$

Where: $P$ is the pressure head $\left(\mathrm{m}^{-1}\right), h$ is the height difference between the tip covered with the sponge and the liquid level, $\rho$ and $\sigma$ are the density $\left(\mathrm{kg} \mathrm{m}^{-3}\right)$ and surface tension $\left(\mathrm{kg} \mathrm{s}^{-2}\right)$ of the liquid, respectively, and $g$ is the acceleration due to gravity $\left(\mathrm{m} \mathrm{s}^{-2}\right)$. This equation indicates that different $h$ values should be applied to different liquids in order to get the same pressure head. In our study, the $h$ values for water and ethanol were 2 and $2.5 \mathrm{~cm}$, respectively.

Cumulative infiltration was recorded by the electronic balance between 0 and $600 \mathrm{~s}$. The flow rate, $\mathrm{Q}\left(\mathrm{mm}^{3} \mathrm{~s}^{-1}\right)$, was obtained from the slope of the linear parts of the curves (cumulative infiltration vs. time). In our study, the steady-state flow was observed within the 300-500 s range. The water and ethanol sorptivity (S) were obtained from the following equation (Leeds-Harrison, Youngs, \& Uddin, 1994):

$$
S=\sqrt{\frac{Q f}{4 b r}}
$$

Where: $f$ is the air-filled porosity $\left(\mathrm{mm}^{3} \mathrm{~mm}^{-3}\right), b$ is a constant that depends on the soil-water diffusivity function and had a value of 0.55 , and $r$ is the infiltrometer tip radius. The sorptivity change with time trend was recorded over 0-600 s. The values for water sorptivity $\left(S_{w}\right)$ and ethanol sorptivity $\left(S_{e}\right)$ were calculated from the steady-state flow rate (300-500 s; Blanco-Canqui \& Lal, 2009; Fischer, Veste, Wiehe, \& Lange, 2010).

Water sorptivity is affected by soil pore structure and water repellency, whereas ethanol sorptivity is only affected by pore structure because ethanol is a nonpolar liquid (Tadayonnejad et al., 2017; Tillman et al., 1989). The water repellency index (RI) was calculated using the following equation (Tillman et al., 1989):

$$
\mathrm{RI}=1.95 \frac{S_{e}}{S_{\mathrm{w}}}
$$

Where: $S_{e}$ is the sorptivity of ethanol $\left(\mathrm{mm} \mathrm{s}^{-1 / 2}\right)$ and $S_{w}$ is the sorptivity of water $\left(\mathrm{mm} \mathrm{s}^{-1 / 2}\right)$. Detailed information about how to calculate the coefficient can be found in Tadayonnejad et al. (2017). Tillman et al. (1989) defined soil with RI > 1.95 as subcritical water repellency.

The soil water contact angle $(\beta)$ was obtained using the $\mathrm{RI}$ as follows:

$$
\beta=\arccos \left(\frac{1}{\mathrm{RI}}\right)
$$

\subsection{2 | Computerized tomography scanning, image processing and morphological analyses}

The core samples were dried in an oven for ten days at $30^{\circ} \mathrm{C}$ before scanning to obtain a better contrast between the solid and porous phases (Parvin, Beckers, Plougonven, Léonard, \& Degré, 2017). The tomographic acquisition was then performed on a high-resolution desktop micro-computed tomography (Skyscan-1172; Skyscan, Kontich, Belgium) at the Chemistry Engineering Laboratory of the University of Liege. The X-ray source was set at $100 \mathrm{kV}$ and $100 \mu \mathrm{A}$, and an aluminum-copper filter was used to reduce beam hardening (Beckers et al., 2014; Smet, Beckers, Plougonven, Léonard, \& Jarvis, 2018). The rotation step for each soil sample was $0.3^{\circ}$ over $180^{\circ}$. Then a 3D reconstruction of these images was created using the NRecon software. During this process, a 0.7 ring artifact correction was used and no beam hardening correction was applied. The reconstructed images had a voxel resolution of $27.27 \times 27.27 \times 27.27 \mu \mathrm{m}^{3}$ and the16-bit TIFF-format 3D images were saved for further processing.

Image preprocessing, segmentation, and quantification were undertaken using the FIJ software and a 3D Gaussian filter with a radius of two pixels was used to reduce noise. An unsharp mask with a standard deviation of one voxel (weight of 0.6) was then applied to emphasize edges (Jarvis et al., 2017). The images had a pixel size of $55 \mu \mathrm{m}$, which also was the minimum size of the recognizable pores. A region of interest that was $1,000 \times 1,000 \times 1,000$ voxel $^{3}$ in size was selected from the central part of the image. An 'opening' operation was used to remove pores that were smaller than the size of the structural mask (Hu, Jon, \& Peng, 2017). The Otsu global threshold 
method (Otsu, 1979) was used to obtain acceptable segmentation results in our study.

We calculated the indexes that describe the porosity, shape, surface area, and connectivity of the pore network from the final binary images. The pore size distribution was calculated using the pore thickness measure, which was defined as the diameter of the largest sphere that fitted into the pore. The calculation was carried out using BoneJ (Doube et al., 2010). There are no uniform standards for the classification of pore size (Lu et al., 2019; Sandin, Koestel, Jarvis, \& Larsbo, 2017). In our study, three pore size classes $(55-165,165-385$, and $>385 \mu \mathrm{m})$ were chosen based on the variation trends of pore size distributions among the three treatments. The degree of anisotropy was also calculated by the BoneJ plugin. The critical pore diameter, connection probability $(\Gamma)$, and special surface area were calculated by SoilJ (Koestel, 2018). The critical pore diameter is defined as the diameter of the largest sphere (bottleneck) that can pass through the pore network from top to bottom and $\Gamma$, a global connectivity measure, is defined as the probability that two voxels belong to the same pore cluster. The $I$ value is 1 when all the voxels in a sample are connected. However, the $\Gamma$ value decreases as the pore space gets fragmented (Koestel \& Schlüter, 2019). The following equation was used to calculate $\Gamma$ :

$$
\Gamma=\frac{\sum_{i=1}^{N} n_{i}^{2}}{\left(\sum_{i=1}^{N} n_{i}\right)^{2}}
$$

Where: $N$ is the number of connected pore clusters, and $n_{i}$ is the number of pore voxel in cluster $i$.

\subsection{3 | Soil organic carbon and microbial biomass carbon}

The samples were acidified with $1.0 \mathrm{M} \mathrm{HCl}$ to decompose the carbonate and then dried at $60^{\circ} \mathrm{C}$ before the $\mathrm{SOC}$ was measured. After drying, the samples were ground $(<0.149 \mathrm{~mm})$ with a mortar and pestle and the SOC was measured by dry combustion method using an elemental analyzer (Vario Macro C/N, Elementar, Germany).

An incubation experiment was carried out before the MBC was measured. Soil samples at $30 \%$ field capacity were kept at a constant temperature $\left(20^{\circ} \mathrm{C}\right)$ environment for 2 weeks to ensure maximum microbial activity. The fumigation extraction method (Vance, Brookes, \& Jenkinson, 1987) was used to calculate MBC. Both fumigated and non-fumigated soil samples were extracted using $0.5 \mathrm{M}$ $\mathrm{K}_{2} \mathrm{SO}_{4}$ for $1 \mathrm{hr}$. The carbon content was measured using a TOC analyzer (Vario TOC, Elementar, Germany).

\subsection{Statistical analysis}

The experimental data for three tillage systems (RT, CT, and NT) in the two experimental fields [Shouyang (S) and Gongzhuling (G)] were analyzed. The sorptivity of water and ethanol, water repellency index, water contact angle, porosity, critical pore diameter, connection probability, special surface area, degree of anisotropy, SOC, and MBC differences among the treatments were analyzed by a one-way analysis of variance (ANOVA), followed by Tukey's post hoc test for paired comparisons $(p<0.05)$, using the SAS 9.4 software. We have detected heterogeneity using Levene's test before carrying out ANOVA and the data for each variable met the heterogeneity of variance criteria. Tillage management had a significant influence on these variables in the two fields $(p<0.05)$. In addition, the Spearman rank-order correlation was analyzed by the PROC CORR procedure in the SAS 9.4 software to determine the initial relationships among these soil properties. Then redundancy analysis (RDA) was used to further understand these relationships and the effect of conservation tillage on SWR using the CANOCO version 5.01 software. Sorptivity, infiltration, water repellency index, and water contact angle were the response variables and the other variables were explanatory variables. Only the uncorrelated explanatory variables were included in the RDA. Pearson's correlations among the physical properties were calculated by SAS 9.4 to avoid omitting the main indexes. If there was a strong correlation $(p<0.001$ ) between two explanatory variables, then only one of the variables was chosen in the RDA (Matamala et al., 2017).

\section{3 | RESULTS}

\section{1 | Sorptivity, infiltration, water repellency index and water contact angle}

The trend for sorptivity change with time, calculated from the infiltration rate over 0-600 s, is shown in Figure 1. Both water and ethanol sorptivity increased rapidly under the three tillage treatments (CT, RT, and NT) at the beginning of the infiltration in the $S$ and $G$ field experiments. Time had no significant influence on sorptivity during $300-500 \mathrm{~s}$ in the two experiments $(p>0.05)$, which suggests that the infiltration was stable during this period. The mean water sorptivity values for CT, RT, and NT, which were calculated using the steadystate flow rate $(300-500 \mathrm{~s})$, were $0.64,0.61$, and $0.50 \mathrm{~mm} \mathrm{~s}^{-1 / 2}$, respectively, and the mean ethanol sorptivity values for $\mathrm{CT}$, RT, and NT were $0.58,0.71$, and $0.67 \mathrm{~mm} \mathrm{~s}^{-1 / 2}$, respectively. The NT treatment had a lower water sorptivity value than RT and CT, whereas CT had the lowest ethanol sorptivity value in the two field experiments. The cumulative ethanol infiltration value of RT treatment was highest and NT treatment had the lowest water infiltration value in the two experiments (Figure 1c,f).

Water repellency index $(\mathrm{RI})$ and water contact angle $(\beta)$ are shown in Figure 2. They were calculated according to the water and ethanol sorptivity during the stable infiltration phase (300-500 s). The RI of NT treatment was 34.7 and $56.9 \%$ higher than the CT treatment in S and $\mathrm{G}$ fields, respectively. The RT treatment was $15.7 \%$ and $37.7 \%$ higher in RI than the CT treatment in the $\mathrm{S}$ and $\mathrm{G}$ fields, respectively. The $\beta$ and RI followed the same trends and the RT and NT treatments increased RI and $\beta$ compared to the $\mathrm{CT}$ treatment in the two fields. In addition, the $\beta$ values for all the samples were less than $90^{\circ}$. 

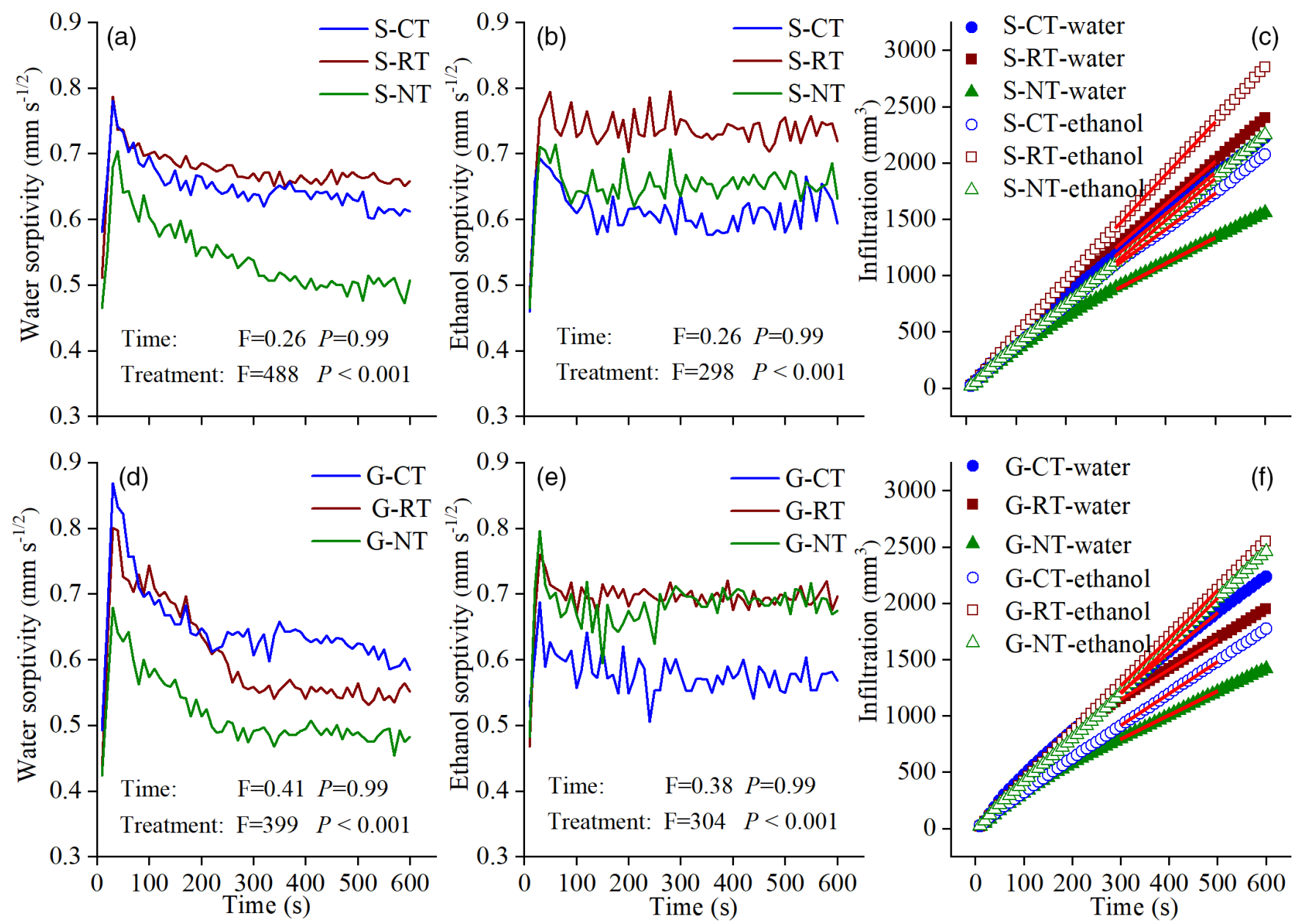

FIGURE 1 Water sorptivity ( $a$ and d), ethanol sorptivity ( $b$ and e), and cumulative infiltration (c and f) of water and ethanol measured with an intrinsic sorptivity method for the three tillage managements (CT, RT, and NT) in Shouyang (S) and Gongzhuling (G) field experiments. The red lines in (c) and ( $\mathrm{f}$ ) represent the stable infiltration range 300-500 s. Two-way ANOVA was used to analyze the effect of time and treatment on sorptivity during 300-500 s [Colour figure can be viewed at wileyonlinelibrary.com]

\subsection{Soil organic carbon and microbial biomass carbon}

The SOC (Figure 3a) and MBC (Figure 3b) were significantly improved after the addition of crop residues under the conservation tillage treatments (RT and NT) in the two field experiments. SOC and MBC are both hydrophobic substances, but they showed different change trends under the three treatments. There was no significant SOC difference between the RT and NT treatments in the two experiments. However, the MBC of the NT treatment was significantly higher than the RT treatment in both experiments $(p<0.05)$.

\section{3 | Characteristics of pore structure}

Tillage management had significant impacts on the pore-size distribution in both field experiments (Figure 4). The two-dimensional image presented a more intuitive comparison of pore-size distribution under the three treatments (Figure 5). The RT and NT treatments increased the porosity of the 55-165 $\mu \mathrm{m}$ diameter pores compared to the CT treatment, which is shown in the representative two-dimensional images of the three tillage management treatments (Figures $5 a-c$ ). The porosity of different pores sizes of RT treatment was the highest compare with CT and NT treatments in the Shouyang site (Figure 4a), whereas the regular changed in the Gongzhuling site (Figure 4b). The total porosity $(>55 \mu \mathrm{m})$ in G-CT treatment was higher than in the GRT and G-NT treatments, and there was a larger porosity of pores $>165 \mu \mathrm{m}$ in diameter under the G-CT treatment than under the G-RT and G-NT treatments (Figure 5d-f). Compared with NT treatment, RT treatment significantly increased the porosity of different pore sizes in both sits $(p<0.05)$.

Critical pore diameter $\left(d_{\text {crit }}\right)$ had different responses to conservation tillage in the two field experiments (Figure 6a). The $d_{\text {crit }}$ for S-CT was not significantly different from S-RT $(p>0.05)$, but was significantly higher than S-NT $(p<0.05)$. The $d_{\text {crit }}$ for G-CT treatment was higher than RT and NT treatments in the G field experiment. The RT and NT treatments increased the connection probability $\Gamma$ 


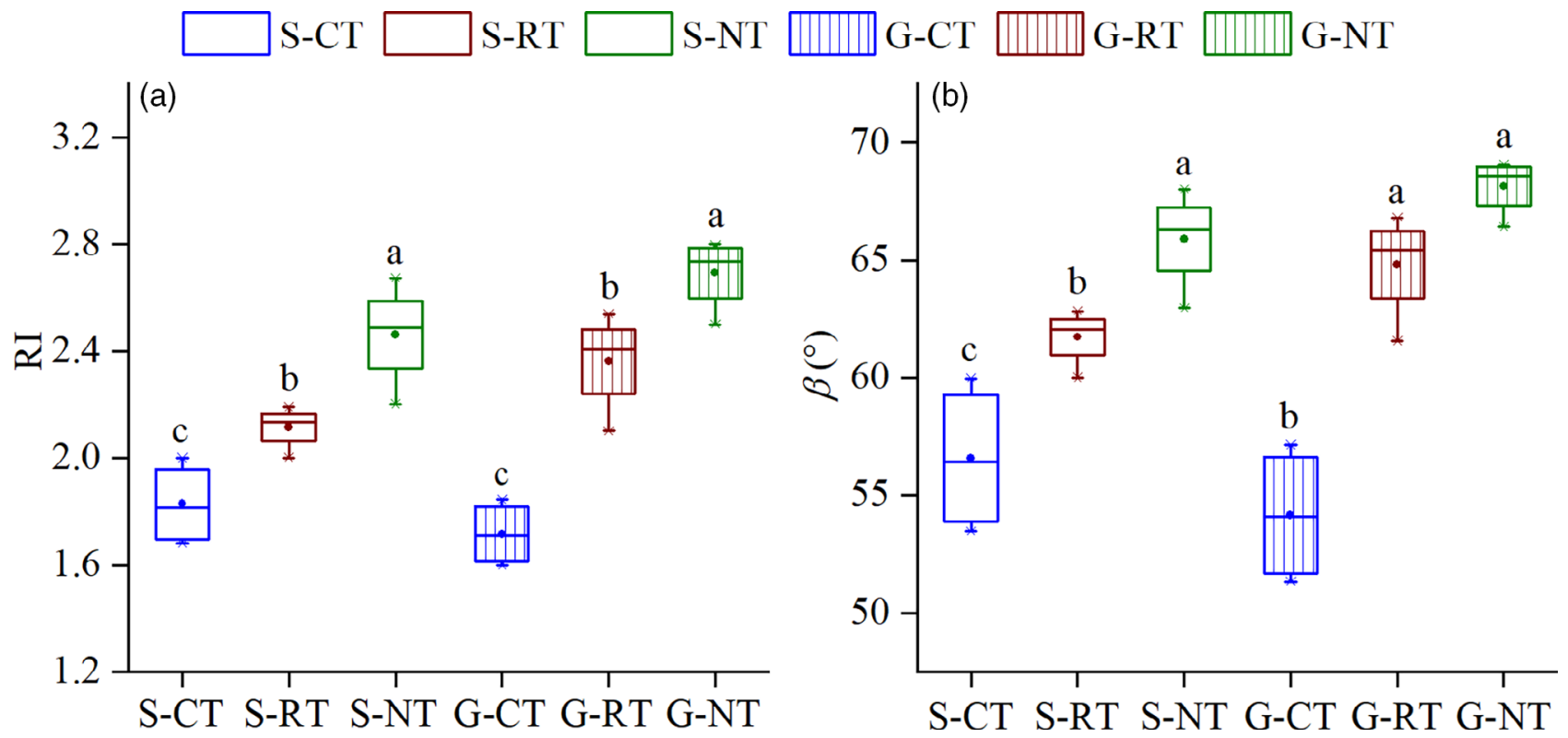

FIGURE 2 Comparisons of (a) water repellency index (RI) and (b) water contact angle ( $\beta$ ) among the three tillage managements (RT, CT, and NT). S and G mean that samples were taken from Shouyang and Gongzhuling field experiments, respectively. Boundaries of the box indicate 25 th quantile, median, and 75th quantiles. The top and bottom whiskers represent the minimum and maximum values, respectively. Dots denote mean values. Values, which were influenced by tillage management in each site, followed by the same letters are not significantly different $(p<0.05)$ according to Tukey's test [Colour figure can be viewed at wileyonlinelibrary.com]

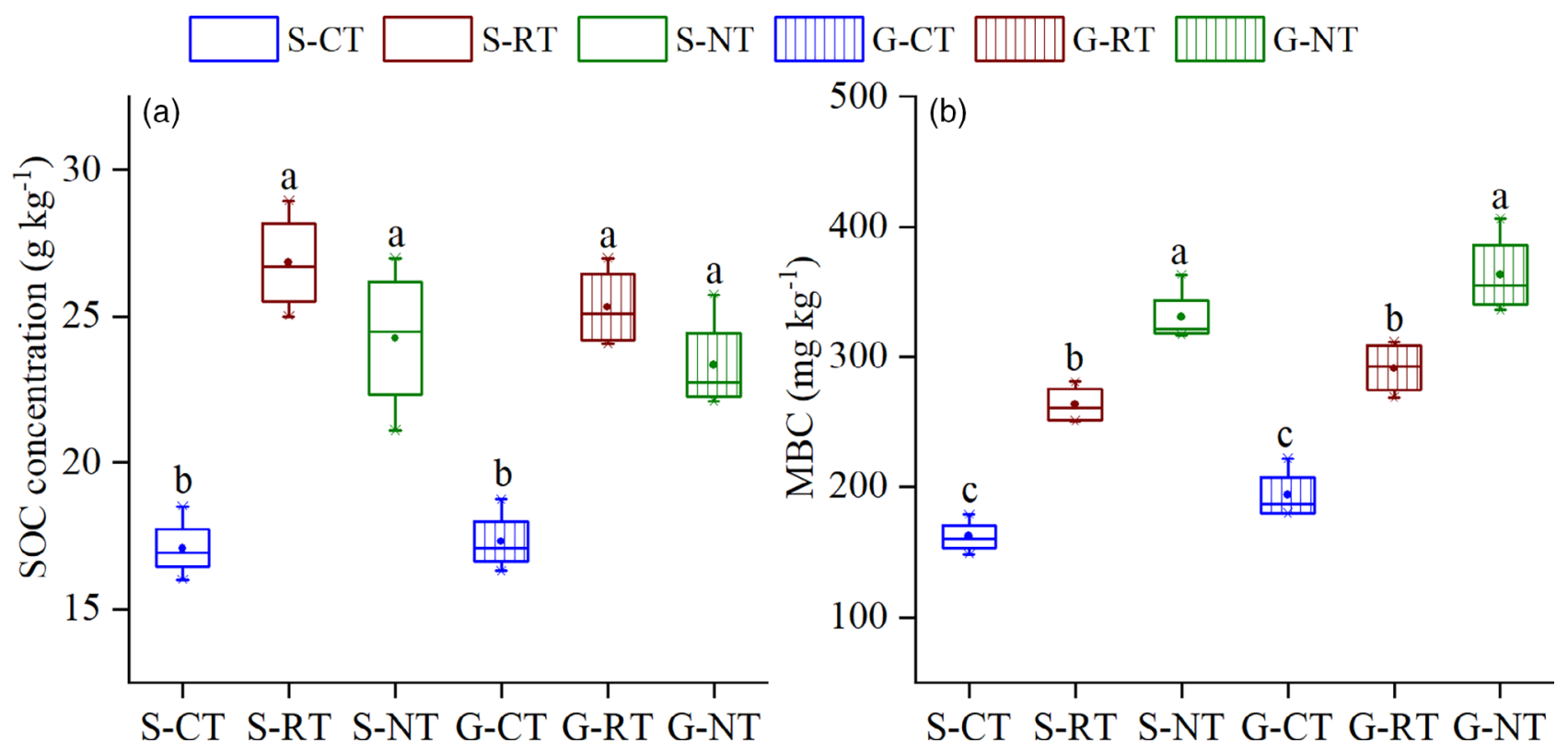

FIGURE 3 Comparisons of (a) soil organic carbon (SOC) and (b) microbial biomass carbon (MBC) among the three tillage managements (RT, $\mathrm{CT}$, and NT). Boundaries of the box indicate 25th quantile, median, and 75th quantiles. The top and bottom whiskers represent the minimum and maximum values, respectively. Dots denote mean values. Values, which were influenced by tillage management in each site, followed by the same letters are not significantly different $(p<0.05)$ according to Tukey's test [Colour figure can be viewed at wileyonlinelibrary.com]

(Figure 6b), specific surface area (Figure 6c), and degree of anisotropy (Figure 6d) compared to $\mathrm{CT}$ in both field experiments. The RT treatment had a greater effect on $\Gamma$ and degree of anisotropy than the NT treatment, whereas the specific surface area in NT was larger than in RT.

\subsection{The impacts of pore structure, SOC, and MBC on SWR under the three tillage managements}

The relationships among SWR, pore structure characteristics, SOC, and $\mathrm{MBC}$ were analyzed in Figure 7. The 55-165 $\mu \mathrm{m}$ diameter pores 

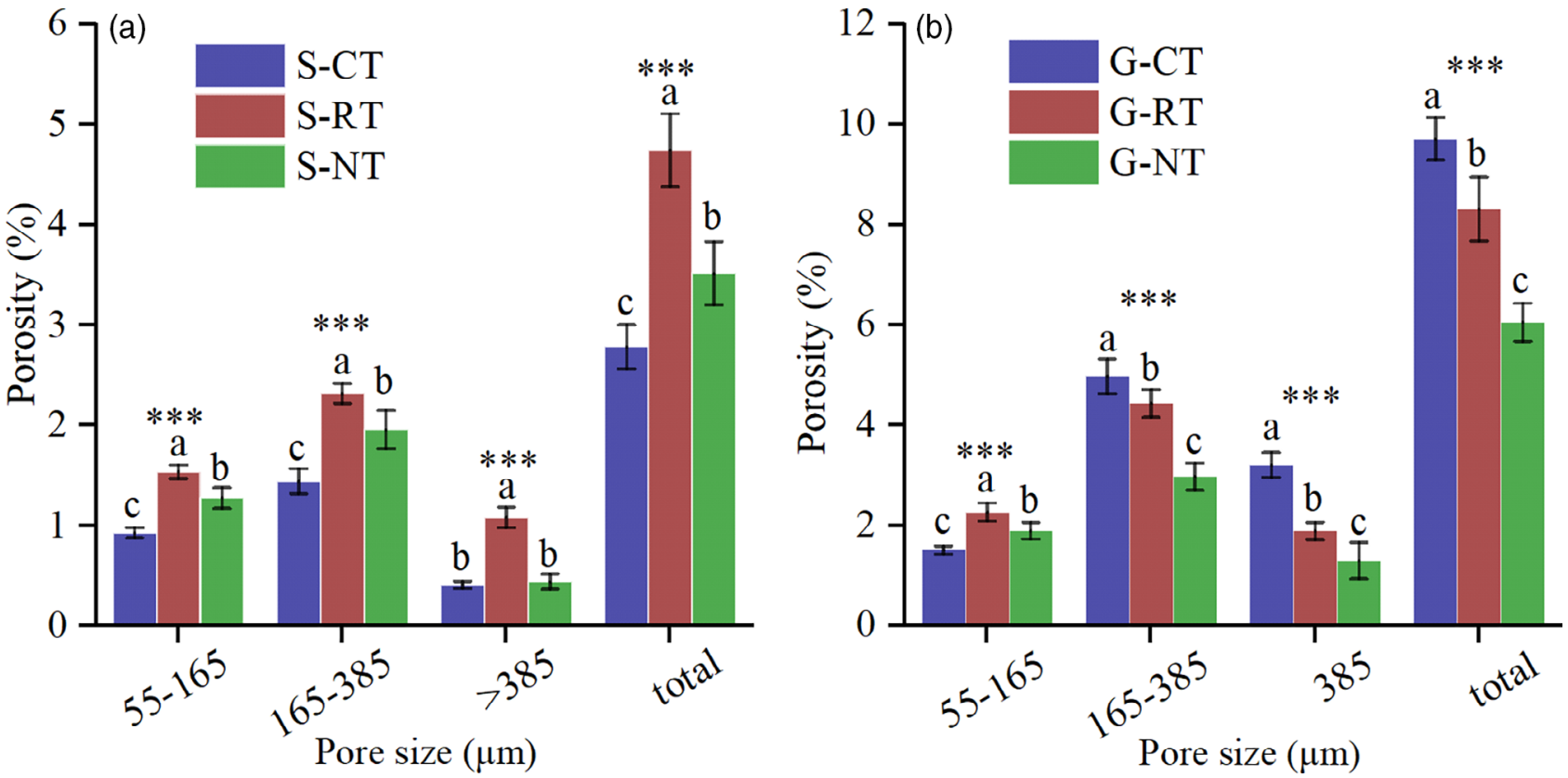

FIGURE 4 Comparison of pore-size distribution among the three tillage managements (RT, CT, and NT) in Shouyang (a) and Gongzhuling (b) field experiments, respectively. Values, which were influenced by tillage management, followed by the same letters are not significantly different $(p<0.05)$ according to Tukey's test. ${ }^{* * *} p<0.001$ [Colour figure can be viewed at wileyonlinelibrary.com]

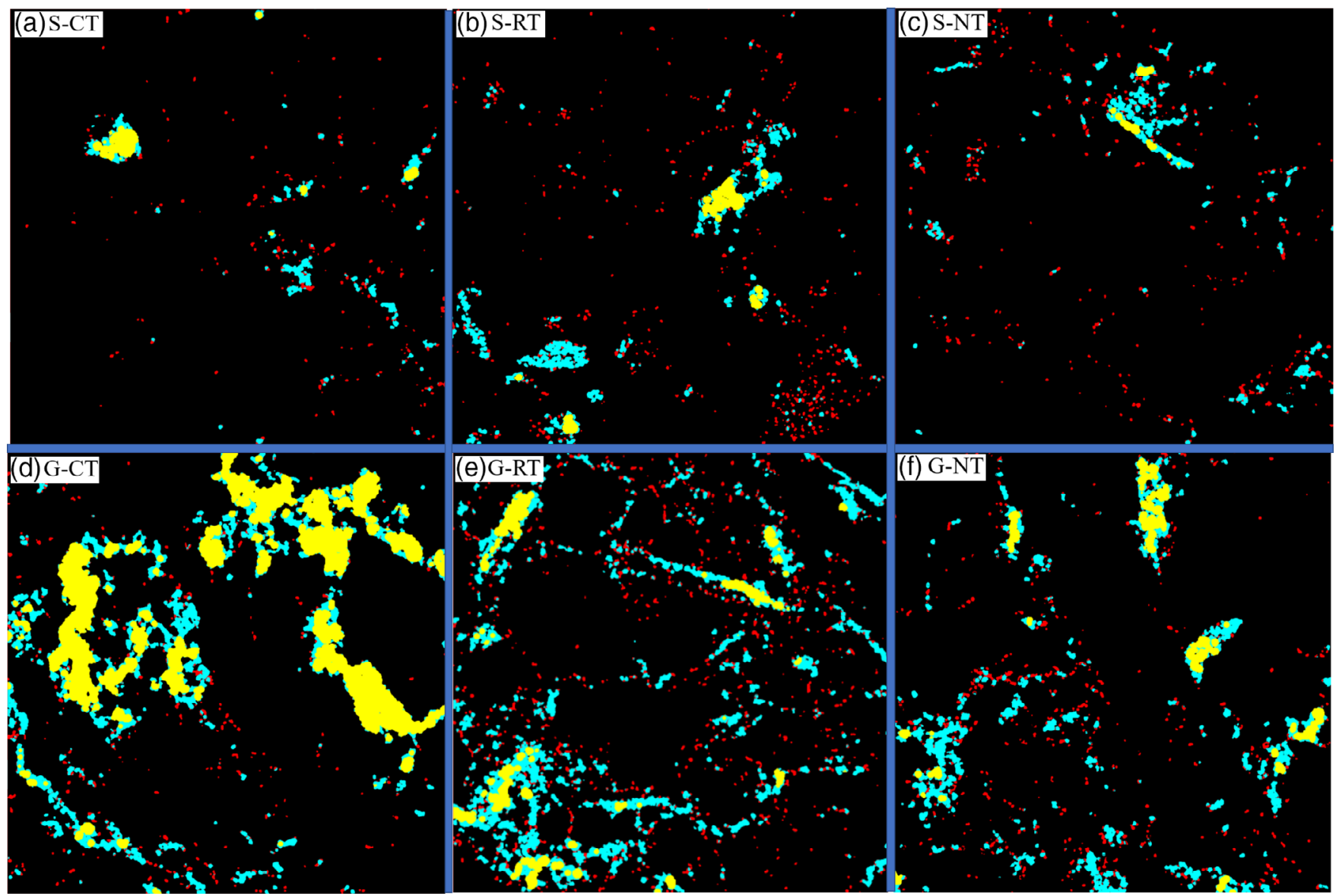

FIGURE 5 Representative two-dimensional images of the three tillage managements (CT, RT, and NT) in Shouyang (S) and Gongzhuling (G) field experiments, respectively. The red area represents pores of 55-165 $\mu \mathrm{m}$; the cyan area represents pores of 165-385 $\mu \mathrm{m}$; the yellow area represents pores larger than $385 \mu \mathrm{m}$ in diameter [Colour figure can be viewed at wileyonlinelibrary.com] 

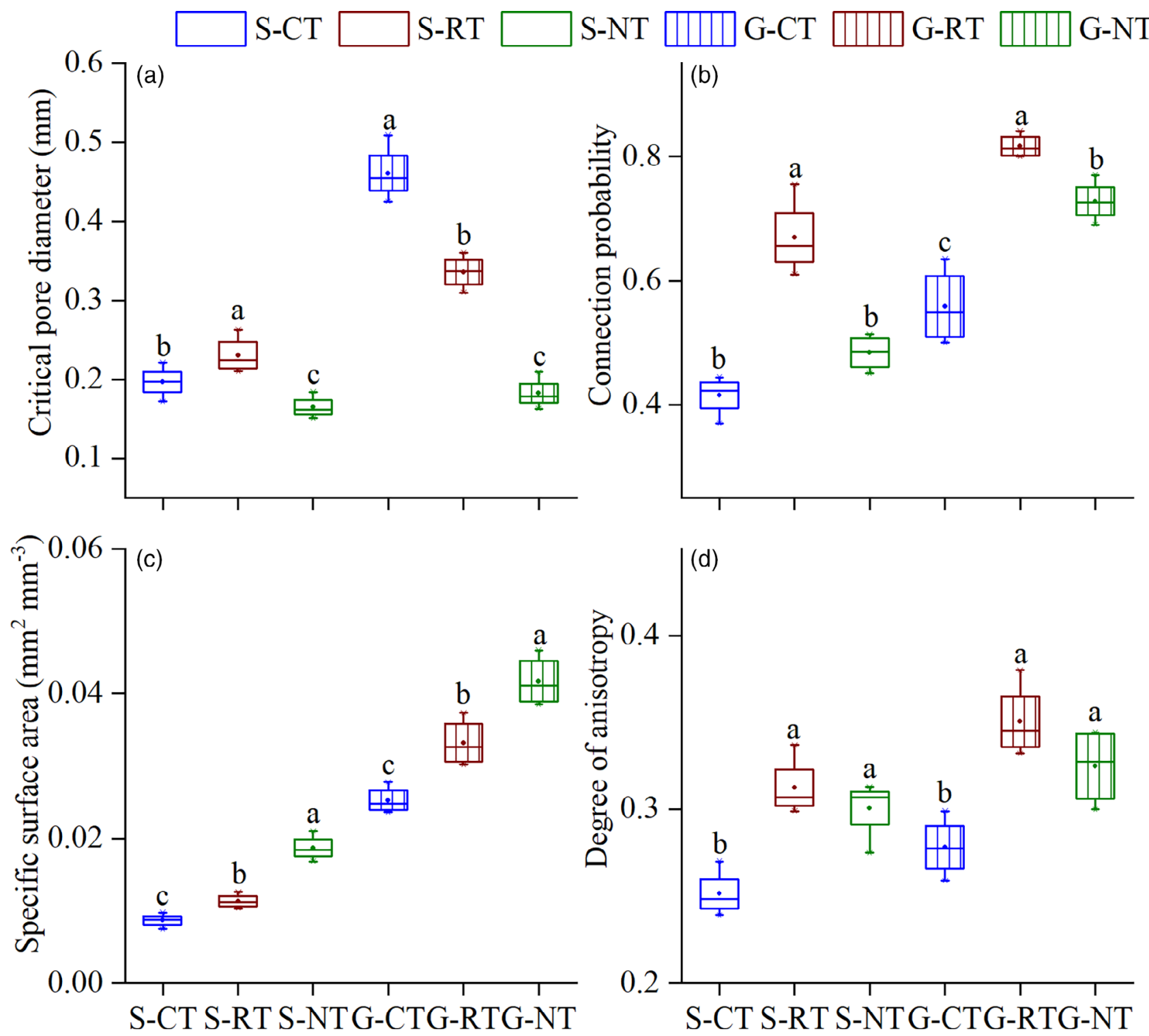

FIGURE 6 Comparisons of (a) critical pore diameter, (b) connection probability, (c) specific surface area, and (d) degree of anisotropy among the three tillage managements (RT, CT, and NT). Boundaries of the box indicate 25th quantile, median, and 75th quantiles. The top and bottom whiskers represent the minimum and maximum values, respectively. Dots denote mean values. Values, which were influenced by tillage management in each site, followed by the same letters are not significantly different $(p<0.05)$ according to Tukey's test [Colour figure can be viewed at wileyonlinelibrary.com]

$\left(\mathrm{P}_{55-165}\right)$ had positive correlations with $\mathrm{S}_{e}$, RI, and $\beta(p<0.05)$. However, there were no significant correlations with sorptivity, infiltration, $\mathrm{RI}$, and $\beta$ when the pore diameter was greater than $165 \mu \mathrm{m}$ (Figure 7). Furthermore, RDA was carried out to reveal how pore structure, SOC, and MBC affected SWR (Figure 8). Its first and second axes accounted for 67.1 and $21.7 \%$ of the total variations, respectively. $S_{w}, I_{w}, R I, \beta$, and $\mathrm{MBC}$ had higher correlations with RDA 1 than other variables and the RDA 2 was mainly controlled by $S_{e}$ and $I_{e}$. We found the porosity of $\mathrm{P}_{55-165}$ increased by the RT and NT treatments had positive correlations with connectivity probability $(\Gamma)$ and specific surface area ( $S_{\text {area }}$; Figures 4 and 8). The $\Gamma$ and $S_{\text {area }}$ also had a positive correlation with RI. In addition, these results suggested that $\Gamma$ increased RI by improving $S_{e}$, whereas $S_{\text {area }}$ increased $\mathrm{RI}$ because there was a reduction in $S_{w}$ (Figures 7 and 8). Both SOC and MBC had positive correlations with $\mathrm{RI}$ and $\beta$, respectively (Figure 7). However, $\mathrm{MBC}$ had a more sensitive response to the $\mathrm{RI}$ and $\beta$ than SOC (Figure 8). The $\mathrm{MBC}$ had a negative correlation with $S_{w}$, but there was no significant correlation between SOC and $S_{w}$ (Figure 7).

\section{DISCUSSION}

Our study showed that conservation tillage had a significant influence on SWR, and RT and NT treatments increased the repellency index (RI) and soil water contact angle $(\beta)$, which confirmed previous results (Behrends et al., 2019; Blanco-Canqui, 2011; González-Peñaloza 


\begin{tabular}{|c|c|c|c|c|c|c|c|c|c|c|c|c|c|c|c|c|}
\hline & $\mathrm{S}_{\mathrm{e}}$ & & & & & & & & & & & & & & & \\
\hline $\mathrm{S}_{\mathrm{e}}$ & 1 & $\mathrm{~S}_{\mathrm{w}}$ & & & & & & & & & & & & & $* * *$ & \\
\hline $\mathrm{S}_{\mathrm{w}}$ & -0.22 & 1 & RI & & & & & & & & & & & & $* *$ & \\
\hline RI & 0.65 & -0.84 & 1 & $\beta$ & & & & & & & & & & & $*$ & \\
\hline$\beta$ & 0.69 & -0.75 & 0.88 & 1 & $\mathrm{I}_{\mathrm{e}}$ & & & & & & & & & & ns & \\
\hline $\mathrm{I}_{e}$ & 0.97 & -0.06 & 0.52 & 0.56 & 1 & $\mathrm{I}_{\mathrm{w}}$ & & & & & & & & & & \\
\hline $\mathrm{I}_{\mathrm{w}}$ & 0.47 & 0.98 & -0.80 & -0.69 & 0.00 & 1 & $P_{55-165}$ & & & & & & & & & \\
\hline $\mathrm{P}_{55-165}$ & \begin{tabular}{|l|}
0.49 \\
\end{tabular} & -0.36 & 0.44 & 0.49 & 0.42 & -0.27 & 1 & $P_{165-385}$ & & & & & & & & \\
\hline$P_{165-38}$ & -0.15 & 0.01 & -0.16 & -0.12 & -0.24 & 0.06 & 0.65 & 1 & $\mathrm{P}_{>385}$ & & & & & & & \\
\hline $\mathrm{P}>385$ & \begin{tabular}{|l|}
-0.34 \\
\end{tabular} & 0.19 & \begin{tabular}{|l|}
-0.37 \\
\end{tabular} & -0.32 & -0.39 & 0.19 & 0.44 & 0.92 & 1 & $\mathrm{P}_{\text {total }}$ & & & & & & \\
\hline $\mathrm{P}_{\text {total }}$ & -0.16 & 0.02 & -0.18 & -0.12 & -0.23 & 0.07 & 0.65 & 0.99 & 0.95 & 1 & $\mathrm{~d}_{\text {crit }}$ & & & & & \\
\hline $\mathrm{d}_{\text {crit }}$ & \begin{tabular}{|l|}
-0.41 \\
\end{tabular} & 0.36 & -0.53 & -0.49 & -0.42 & 0.40 & 0.29 & 0.88 & \begin{tabular}{|l|}
0.92 \\
\end{tabular} & 0.88 & 1 & $\Gamma$ & & & & \\
\hline$\Gamma$ & 0.64 & -0.27 & 0.46 & 0.53 & 0.58 & -0.19 & 0.91 & 0.52 & 0.34 & 0.54 & 0.20 & 1 & $\mathrm{~S}_{\text {area }}$ & & & \\
\hline $\mathrm{S}_{\text {area }}$ & 0.19 & \begin{tabular}{|l|}
-0.69 \\
\end{tabular} & 0.55 & 0.54 & 0.04 & -0.67 & 0.74 & 0.57 & 0.43 & 0.59 & 0.19 & 0.68 & 1 & $\mathrm{Da}$ & & \\
\hline $\mathrm{Da}$ & 0.72 & -0.42 & 0.65 & 0.67 & 0.62 & -0.30 & 0.83 & 0.38 & 0.11 & 0.34 & 0.04 & 0.83 & 0.57 & 1 & SOC & \\
\hline $\mathrm{SOC}$ & 0.83 & -0.35 & 0.67 & 0.69 & 0.77 & -0.26 & 0.51 & -0.09 & -0.25 & -0.09 & -0.31 & 0.55 & 0.18 & 0.65 & 1 & $\mathrm{MBC}$ \\
\hline $\mathrm{MBC}$ & 0.68 & -0.79 & 0.93 & 0.87 & 0.53 & -0.74 & 0.52 & 0.00 & -0.21 & -0.02 & -0.41 & 0.51 & 0.59 & 0.44 & 0.65 & 1 \\
\hline
\end{tabular}

FIGURE 7 Spearman rank-order correlation analysis for all samples. $S_{e}$ : ethanol sorptivity; $\boldsymbol{S}_{w}$ : water sorptivity; RI: water repellency index; $\beta$ : water contact angle; $I_{e}$ : ethanol accumulative infiltration; $I_{w}$ : water accumulative infiltration; P55-165: pores of 55-165 $\mu \mathrm{m}$ in diameter; P165-385: pores of 165-385 $\mu \mathrm{m}$ in diameter; $P>385$ : pores greater than $385 \mu \mathrm{m}$ in diameter; $P_{\text {total: }}$ total porosity; dcrit: critical pore diameter; $\Gamma$ : connection probability; $S_{\text {area: }}$ special surface area; $D_{a}$ : degree of anisotropy; SOC: soil organic carbon; MBC: microbial biomass carbon. ${ }^{* * *} p<0.001{ }^{* *} p<0.01 ;{ }^{*} p<0.05$; ns: not significant [Colour figure can be viewed at wileyonlinelibrary.com]

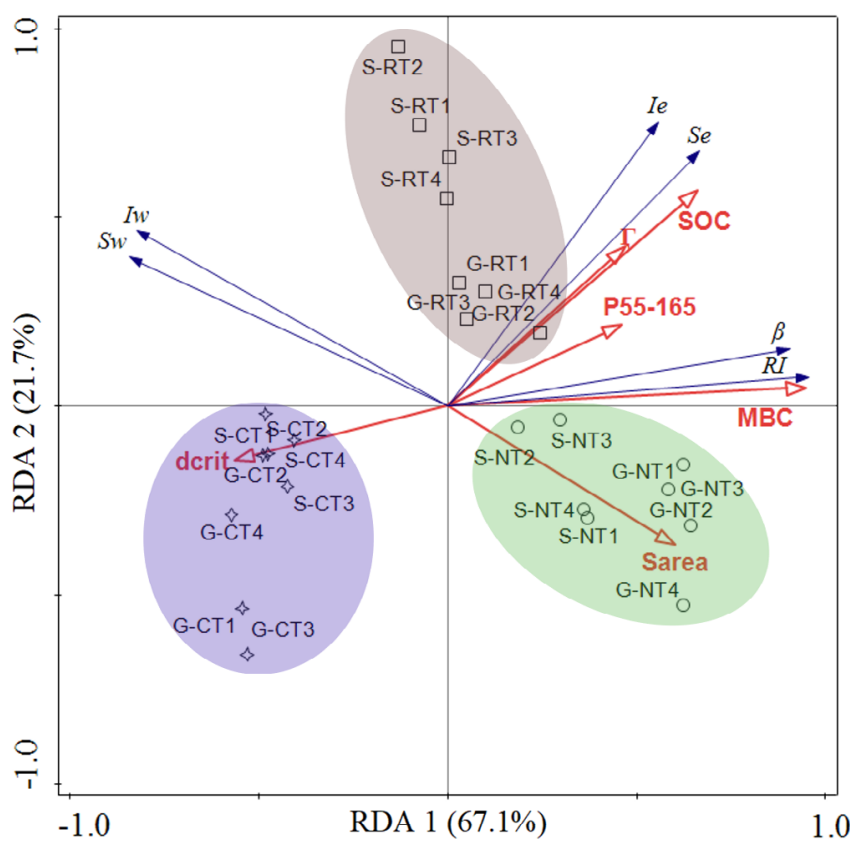

FIGURE 8 Redundancy analysis of the effects of pore structure, $\mathrm{SOC}$, and MBC on SWR. The response variables are $S_{e}, S_{w}, I_{e}, I_{w}, \mathrm{RI}$, and $\beta$. The explanatory variables are P55-165, dcrit, $\Gamma$, Sarea, SOC, and MBC. See Figure 7 for abbreviations of these variables [Colour figure can be viewed at wileyonlinelibrary.com]

et al., 2012). It has been stated that soil is hydrophobic if the $\beta$ is greater than $90^{\circ}$ (Carrillo, Yates, \& Letey, 1999; Gordon, Stavi, Shavit, \& Rosenzweig, 2018; Xiong, Furman, \& Wallach, 2012). This is true for cylindrical pores. However, it does not really apply to wavy pores in the soil and where the hydrophobicity begins to emerge when the critical water angle is much smaller than $90^{\circ}$ (Czachor, Doerr, \& Lichner, 2010). In our study, the contact angle values under the three treatments ranged from $54^{\circ}$ to $68^{\circ}$ in the two field experiments. Similar results were reported by Behrends et al. (2019). In addition, a slight change in $\beta$ can have a considerable effect on soil hydraulic properties (Leelamanie \& Karube, 2013; Tadayonnejad et al., 2017). Therefore, it is important to determine the impact of conservation tillage on SWR, even if the water contact angle is less than $90^{\circ}$.

Most previous studies have used SOC to represent hydrophobic substances (Jimenez-Morillo et al., 2016; Zavala et al., 2009) and they found that the degree of SWR increased with an increase in SOC (Jimenez-Morillo et al., 2016; Zheng et al., 2016). In this study, the RI showed a positive correlation with SOC, but there was no relationship between water sorptivity $\left(S_{w}\right)$ and SOC (Figure 7). Hallett et al. (2001) also reported similar results for plowing and no-tillage systems. In addition, we undertook a redundancy analysis and found that $M B C$ had a closer relationship with RI than SOC (Figure 8). This is because that the MBC, rather than the total SOC, showed more useful and sensitive responses to soil processes (Sparling, 1992). Previous researchers also found that soil microbial community composition strongly influenced SWR (Behrends et al., 2019; Seaton et al., 2019). Furthermore, the $\mathrm{MBC}$ had a negative correlation with $S_{w}$ and a positive correlation with the RI (Figure 7). This can be supported by the result that there was a positive relationship between $\mathrm{MBC}$ and the RI when a straw amendment was applied (Zhang, Yao, \& Hu, 2007). 
Therefore, although most of the previous studies used SOC to explain SWR (Jimenez-Morillo et al., 2016; Zavala et al., 2009), our results suggested that $M B C$ produced more useful information about the effects of different factors on SWR than SOC.

We found the RT and NT treatments increased the porosity of pores in the 55-165 $\mu \mathrm{m}$ diameter range compared to CT treatment (Figures 4 and 5). Borges et al. (2019) used the soil water retention curve method to show that NT treatment had a greater effect on the porosity of the $30-70 \mu \mathrm{m}$ diameter pores than CT treatment. Only the pores in the 55-165 $\mu \mathrm{m}$ diameter range had a positive correlation with $S_{e}, \mathrm{RI}$, and $\beta$ (Figure 7). The reason is that soil water first infiltrates into small pores during the infiltration process (Parvin et al., 2017) because the small pores have higher suction (Hu et al., 2017), which causes the pores in the 55-165 $\mu \mathrm{m}$ diameter range have a closer relationship with SWR compared to the pores with a diameter $>165 \mu \mathrm{m}$ (Figure 7). In addition, previous studies have shown that connectivity probability $(\Gamma)$ that is measured by percolation theory concepts (Jarvis et al., 2017; Schlüter \& Vogel, 2011) could influence soil hydraulic properties (Sandin et al., 2017). In our study, $\Gamma$ had a positive correlation with RI and $S_{e}$, but there was no significant correlation between $\Gamma$ and $S_{w}$ (Figure 7). This showed that the RT and NT treatments increased soil pore connectivity, but water sorptivity was not increased. This challenges the traditional view that increasing soil pore connectivity could improve soil hydraulic conductivity (Borges et al., 2019; Schlüter, Albrecht, Schwärzel, \& Kreiselmeier, 2020). The main reason may be that the increase in hydrophobic substances under RT and NT treatments could reduce water sorptivity (Hallett et al., 2001; Liu, Ma, Hu, \& Li, 2018). Furthermore, an increase in the critical pore diameter $\left(d_{\text {crit }}\right)$ usually enhances saturated hydraulic conductivity and water infiltration (Koestel et al., 2018; Koestel \& Schlüter, 2019). However, in our study, $d_{\text {crit }}$ had a negative correlation with $S_{e}, l_{e}$, and RI (Figure 7). The reason was that the $d_{\text {crit }}$ value was greater than $165 \mu \mathrm{m}$ in the three treatments (Figure 6), but the larger pores $(>165 \mu \mathrm{m})$ had no significant influence on SWR properties (Figure 7). Therefore, $d_{\text {crit }}$ had no influence on SWR properties under the three tillage management.

The RT and NT treatments improved the porosity $(55-165 \mu \mathrm{m})$ and connectivity to increase $S_{e}$ (Figure 8 ) and the capacity of soil water absorption. However, the increase of $S_{\text {area }}$ in the RT and NT treatments also increased the possibility and area of contact between soil water and hydrophobic compounds (Allen, 2007; Greco \& Gargano, 2015), which intensified the capacity limitation of soil water absorption and then led to an increase in the RI. More importantly, the results indicated that the addition of crop residues under the RT and NT treatments not only increased sorptivity by enhancing porosity and connectivity but also decreased water sorptivity by increasing $S_{\text {area }}$ due to the increase in the potential contacts between hydrophobic substances and soil water (Allen, 2007; Greco \& Gargano, 2015). These results challenge the traditional view that the addition of crop residues increases sorptivity and reduces water repellency by improving pore structure (Cosentino et al., 2010).

Previous studies were not based on the direct measurements of pore structure and their results were obtained using other indirect methods associated with pore structure. There are obvious limitations in using indirect variables (e.g., ethanol sorptivity) to explain the effect of pore structure on SWR. Our results came from two experimental fields with different soil types, climate, and length of time that the tillage systems were used. These factors could also affect pore structure, SOC, MBC, and SWR. However, the impact of pore structure and hydrophobic substances on SWR could still be determined for each field. This reinforces our conclusions. The results from this study, calculated by $\mathrm{X}$-ray computed tomography, have improved our understanding of the effect of pore structure characteristics on SWR. In addition, the WDPT method, which is often used to measure SWR, defines the time needed for a single water drop to infiltrate a soil sample (Hallin, Douglas, Doerr, \& Bryant, 2013), but the infiltration time is controlled by two factors, which are hydrophobic substances and pore structure (Behrends et al., 2019). This also suggests that it is essential to take both pore structure and hydrophobic substances into account when studying the factors governing SWR. In our study, although ethanol sorptivity increased under RT and NT treatments because porosity and connectivity improved, water sorptivity decreased due to the increase in hydrophobic substances and $S_{\text {area }}$ (Figures 7 and 8). Therefore, the degree of SWR is controlled by the interactions between pore structure and hydrophobic substances under conservation tillage management.

\section{5 | CONCLUSIONS}

X-ray computed tomography made it possible to better understand the impacts of pore structure and hydrophobic substances on SWR. Although SWR is induced by hydrophobic substances, pore structure can also affect its degree and behavior. The RT and NT treatments improved porosity and connectivity, which enhanced ethanol sorptivity, whereas the increase in pore surface area $\left(S_{\text {area }}\right)$ under the two treatments led to a decrease in water sorptivity because the rise in $S_{\text {area }}$ increased the possibility of contact between the soil water and hydrophobic substances. In addition, the RT and NT treatments increased water repellency index (RI) by improving MBC and SOC. However, MBC had a closer relationship with RI than SOC and more fully explained the impact of tillage on SWR. Although porosity and connectivity improved sorptivity, the degree of SWR for the two conservation tillage managements (RT and NT) still increased, which was due to the increase in MBC, SOC, and $S_{\text {area. }}$. The change in pore structure after the addition of maize residues increased sorptivity by improving porosity and connectivity, but decreased water sorptivity by increasing $S_{\text {area }}$ due to the hydrophobicity. Therefore, the effect of conservation tillage on SWR is a result of the interactions between pore structure and hydrophobic substances. Future studies should take into account both pore structure and hydrophobic substances when studying the impacts of SWR on soil processes.

\section{ACKNOWLEDGMENTS}

This research was supported by the National Key Research and Development Program of China (2018YFE0112300), National Key Research 
Development Program of China (2018YFD0200408), Science and Technology Project (2015BAD22B03). We wish to thank the editors and reviewers for their constructive comments.

\section{DATA AVAILABILITY STATEMENT}

The data that support the findings of this study are available from the corresponding author upon reasonable request.

\section{ORCID}

Shengping Li (D) https://orcid.org/0000-0001-6940-9179

Guopeng Liang (D) https://orcid.org/0000-0001-5514-785X

Erwan Plougonven (D) https://orcid.org/0000-0003-2935-8121

\section{REFERENCES}

Allen, M. F. (2007). Mycorrhizal fungi: Highways for water and nutrients in arid soils. Vadose Zone Journal, 6, 291-297. https://doi.org/10.2136/ vzj2006.0068

Arns, C. H., Knackstedt, M. A., \& Martys, N. S. (2005). Cross-property correlations and permeability estimation in sandstone. Physical Review EStatistical, Nonlinear, and Soft Matter Physics, 72, 1-12. https://doi. org/10.1103/PhysRevE.72.046304

Atanassova, I., \& Doerr, S. H. (2011). Changes in soil organic compound composition associated with heat-induced increases in soil water repellency. European Journal of Soil Science, 62, 516-532. https://doi. org/10.1111/j.1365-2389.2011.01350.x

Beckers, E., Plougonven, E., Roisin, C., Hapca, S., Léonard, A., \& Degré, A. (2014). X-ray microtomography: A porosity-based thresholding method to improve soil pore network characterization? Geoderma, 220, 145-154. https://doi.org/10.1016/j.geoderma.2014.01.004

Behrends, F., Hallett, P. D., Morrás, H., Garibaldi, L., Cosentino, D., Duval, M., \& Galantini, J. (2019). Soil stabilisation by water repellency under no-till management for soils with contrasting mineralogy and carbon quality. Geoderma, 355, 113902. https://doi.org/10.1016/j. geoderma.2019.113902

Blanco-Canqui, H. (2011). Does no-till farming induce water repellency to soils? Soil Use and Management, 27, 2-9. https://doi.org/10.1111/j. 1475-2743.2010.00318.x

Blanco-Canqui, H., \& Lal, R. (2009). Extent of soil water repellency under long-term no-till soils. Geoderma, 149, 171-180. https://doi.org/10. 1016/j.geoderma.2008.11.036

Blanco-Canqui, H., \& Ruis, S. J. (2018). No-tillage and soil physical environment. Geoderma, 326, 164-200. https://doi.org/10.1016/j.geoderma. 2018.03.011

Borges, J. A. R., Pires, L. F., Cássaro, F. A. M., Auler, A. C., Rosa, J. A., Heck, R. J., \& Roque, W. L. (2019). X-ray computed tomography for assessing the effect of tillage systems on topsoil morphological attributes. Soil \& Tillage Research, 189, 25-35. https://doi.org/10.1016/j. still.2018.12.019

Carrillo, M. L. K., Yates, S. R., \& Letey, J. (1999). Measurement of initial soil-water contact angle of water repellent soils. Soil Science Society of America Journal, 63, 433-436. https://doi.org/10.2136/sssaj1999. $03615995006300030002 x$

Cosentino, D., Hallett, P. D., Michel, J. C., \& Chenu, C. (2010). Do different methods for measuring the hydrophobicity of soil aggregates give the same trends in soil amended with residue? Geoderma, 159, 221-227. https://doi.org/10.1016/j.geoderma.2010.07.015

Czachor, H., Doerr, S. H., \& Lichner, L. (2010). Water retention of repellent and subcritical repellent soils: New insights from model and experimental investigations. Journal of Hydrology, 380, 104-111. https://doi. org/10.1016/j.jhydrol.2009.10.027

Daniel, N. R. R., Uddin, S. M. M., Harper, R. J., \& Henry, D. J. (2019). Soil water repellency: A molecular-level perspective of a global environmental phenomenon. Geoderma, 338, 56-66. https://doi.org/ 10.1016/j.geoderma.2018.11.039

Debano, L. F. (2000). The role of fire and soil heating on water repellency in wildland environments: A review. Journal of Hydrology, 231-232, 195-206. https://doi.org/10.1016/S0022-1694(00)00194-3

Dekker, L. W., Ritsema, C. J., \& Oostindie, K. (2000). Extent and significance of water repellency in dunes along the Dutch coast. Journal of Hydrology, 231, 112-125. https://doi.org/10.1016/s0022-1694(00) 00188-8.

Doerr, S. H., Shakesby, R. A., \& Walsh, R. P. D. (2000). Soil water repellency: Its causes, characteristics and hydro-geomorphological significance. Earth Science Reviews, 51, 33-65. https://doi.org/10.1016/ S0012-8252(00)00011-8

Doube, M., Klosowski, M. M., Arganda-Carreras, I., Cordelières, F. P., Dougherty, R. P., Jackson, J. S., ... Shefelbine, S. J. (2010). BoneJ: Free and extensible bone image analysis in ImageJ. Bone, 47, 1076-1079. https://doi.org/10.1016/j.bone.2010.08.023

Fang, H., Zhang, Z., Li, D., Liu, K., Zhang, K., \& Zhang, W. (2019). Temporal dynamics of paddy soil structure as affected by different fertilization strategies investigated with soil shrinkage curve. Soil \& Tillage Research, 187, 102-109. https://doi.org/10.1016/j.still. 2018.12.006

Fischer, T., Veste, M., Wiehe, W., \& Lange, P. (2010). Water repellency and pore clogging at early successional stages of microbiotic crusts on inland dunes, Brandenburg, NE Germany. Catena, 80, 47-52. https:// doi.org/10.1016/J.CATENA.2009.08.009

Fontaine, S., Mariotti, A., \& Abbadie, L. (2003). The priming effect of organic matter: a question of microbial competition? Soil Biology and Biochemistry, 35, 837-843. https://doi.org/10.1016/S0038-0717(03) 00123-8

Gao, L., Wang, B., Li, S., Han, Y., Zhang, X., Gong, D., ... Degré, A. (2019). Effects of different long-term tillage systems on the composition of organic matter by $13 \mathrm{C} \mathrm{CP/TOSS} \mathrm{NMR} \mathrm{in} \mathrm{physical} \mathrm{fractions} \mathrm{in} \mathrm{the}$ Loess Plateau of China. Soil and Tillage Research, 194, 104321. https:// doi.org/10.1016/j.still.2019.104321

Ghanbarian, B., Torres-Verdín, C., \& Skaggs, T. H. (2016). Quantifying tight-gas sandstone permeability via critical path analysis. Advances in Water Resources, 92, 316-322. https://doi.org/10.1016/j.advwatres. 2016.04.015

Girona-garcía, A., Ortiz-perpiñá, O., Badía-villas, D., \& Martí-dalmau, C. (2018). Effects of prescribed burning on soil organic C, aggregate stability and water repellency in a subalpine shrubland: Variations among sieve fractions and depths. Catena, 166, 68-77. https://doi.org/10. 1016/j.catena.2018.03.018

González-Peñaloza, F. A., Cerdà, A., Zavala, L. M., Jordán, A., GiménezMorera, A., \& Arcenegui, V. (2012). Do conservative agriculture practices increase soil water repellency? A case study in citrus-cropped soils. Soil and Tillage Research, 124, 233-239. https://doi.org/10. 1016/j.still.2012.06.015

Gordon, G., Stavi, I., Shavit, U., \& Rosenzweig, R. (2018). Oil spill effects on soil hydrophobicity and related properties in a hyper-arid region. Geoderma, 312, 114-120. https://doi.org/10.1016/j.geoderma.2017. 10.008

Greco, R., \& Gargano, R. (2015). A novel equation for determining the suction stress of unsaturated soils from the water retention curve based on wetted surface area in pores. Water Resources Research, 51, 6143-6155. https://doi.org/10.1002/2014WR016541

Hallett, P. D., Baumgartl, T., \& Young, I. M. (2001). Subcritical water repellency of aggregates from a range of soil management practices. Soil Science Society of America Journal, 65, 184-190. https://doi.org/10. 2136/sssaj2001.651184x

Hallett, P. D., \& Young, I. M. (1999). Changes to water repellence of soil aggregates caused by substrate-induced microbial activity. European Journal of Soil Science, 50(1), 35-40. https://doi.org/10.1046/j.13652389.1999.00214.x 
Hallin, I., Douglas, P., Doerr, S. H., \& Bryant, R. (2013). The role of drop volume and number on soil water repellency determination. Soil Science Society of America Journal, 77, 1732-1743. https://doi.org/10. 2136/sssaj2013.04.0130

Han, D., \& Zhou, T. (2018). Soil water movement in the unsaturated zone of an inland arid region: Mulched drip irrigation experiment. Journal of Hydrology, 559, 13-29. https://doi.org/10.1016/j.jhydrol.2018. 02.012

Hu, Z., Jon, S., \& Peng, X. (2017). Bimodal soil pore structure investigated by a combined soil water retention curve and X-Ray computed tomography approach. Soil Science Society of America Journal, 81(6), 1270-1278. https://doi.org/10.2136/sssaj2016.10.0338

Hunter, A. E., Chau, H. W., \& Si, B. C. (2011). Impact of tension infiltrometer disc size on measured soil water repellency index. Canadian Journal of Soil Science, 91, 77-81. https://doi.org/10.4141/ CJSS10033

Jarvis, N., Larsbo, M., \& Koestel, J. (2017). Connectivity and percolation of structural pore networks in a cultivated silt loam soil quantified by $\mathrm{X}$ ray tomography. Geoderma, 287, 71-79. https://doi.org/10.1016/j. geoderma.2016.06.026

Jimenez-Morillo, N. T., Gonzalez-Perez, J. A., Jordan, A., Zavala, L. M., de la Rosa, J., Jimenez-Gonzalez, M. A., \& Gonzalez-Vila, F. J. (2016). Organic matter fractions controlling soil water repellency in sandy soils from the Donana National Park (Southwestern Spain). Land Degradation \& Development, 27, 1413-1423. https://doi.org/10.1002/ldr. 2314

Katuwal, S., Norgaard, T., Moldrup, P., Lamandé, M., Wildenschild, D., \& de Jonge, L. W. (2015). Linking air and water transport in intact soils to macropore characteristics inferred from X-ray computed tomography. Geoderma, 237-238, 9-20. https://doi.org/10.1016/j.geoderma.2014. 08.006

Koestel, J. (2018). SoilJ: An imagej plugin for the semiautomatic processing of three-dimensional X-ray images of soils. Vadose Zone Journal, 17, 1-7. https://doi.org/10.2136/vzj2017.03.0062

Koestel, J., Dathe, A., Skaggs, T. H., \& Klakegg, O. (2018). Estimating the permeability of naturally structured soil from percolation theory and pore space characteristics imaged by X-ray. Water Resources Research, 54(11), 9255-9263. https://doi.org/10.1029/2018WR023609

Koestel, J., \& Schlüter, S. (2019). Quantification of the structure evolution in a garden soil over the course of two years. Geoderma, 338 , 597-609. https://doi.org/10.1016/j.geoderma.2018.12.030

Leeds-Harrison, P. B., Youngs, E. G., \& Uddin, B. (1994). A device for determining the sorptivity of soil aggregates. European Journal of Soil Science, 45, 269-272. https://doi.org/10.1111/j.1365-2389.1994. tb00509.x

Leelamanie, D. A. L., \& Karube, J. (2013). Soil-water contact angle as affected by the aqueous electrolyte concentration. Soil Science and Plant Nutrition, 59, 501-508. https://doi.org/10.1080/00380768. 2013.809601

Li, Y., Yao, N., Tang, D., Chau, H. W., \& Feng, H. (2019). Soil water repellency decreases summer maize growth. Agricultural and Forest Meteorology, 266-267, 1-11. https://doi.org/10.1016/j.agrformet.2018. 12.001

Liu, Z., Ma, D., Hu, W., \& Li, X. (2018). Land use dependent variation of soil water infiltration characteristics and their scale-specific controls. Soil and Tillage Research, 178, 139-149. https://doi.org/10.1016/j.still. 2018.01.001

Lu, S., Yu, X., \& Zong, Y. (2019). Nano-microscale porosity and pore size distribution in aggregates of paddy soil as affected by long-term mineral and organic fertilization under rice-wheat cropping system. Soil \& Tillage Research, 186, 191-199. https://doi.org/10.1016/j.still.2018. 10.008

Lucas-Borja, M. E., Zema, D. A., Antonio Plaza-álvarez, P., Zupanc, V., Baartman, J., Sagra, J., ... de las Heras, J. (2019). Effects of different land uses (abandoned farmland, intensive agriculture and forest) on soil hydrological properties in Southern Spain. Water, 11, 1-14. https://doi.org/10.3390/w11030503

Madsen, M. D., Zvirzdin, D. L., Petersen, S. L., Hopkins, B. G., Roundy, B. A., \& Chandler, D. G. (2011). Soil water repellency within a burned piñon-juniper woodland: spatial distribution, severity, and ecohydrologic implications. Soil Science Society of America Journal, 75, 1543-1553. https://doi.org/10.2136/sssaj2010.0320

Martínez-garcía, L. B., Korthals, G., Brussaard, L., Bracht, H., \& De, D. G. B. (2018). Organic management and cover crop species steer soil microbial community structure and functionality along with soil organic matter properties. Agriculture, Ecosystems and Environment, 263, 7-17. https://doi.org/10.1016/j.agee.2018.04.018

Mataix-Solera, J., Arcenegui, V., Zavala, L. M., Pérez-Bejarano, A., Jordán, A., Morugán-Coronado, A., ... Gil-Torres, J. (2014). Controlo por pequenas alterações nas propriedades do solo da repelência de água induzida através do fogo. Spanish Journal of Soil Science, 4, 51-60. https://doi.org/10.3232/SJSS.2014.V4.N1.03

Matamala, R., Calderón, F. J., Jastrow, J. D., Fan, Z., Hofmann, S. M. Michaelson, G. J., ... Ping, C. L. (2017). Influence of site and soil properties on the DRIFT spectra of northern cold-region soils. Geoderma, 305, 80-91. https://doi.org/10.1016/j.geoderma.2017.05.014

Miller, J. J., Owen, M. L., Yang, X. M., Drury, C. F., Reynolds, W. D., \& Chanasyk, D. S. (2019). Tillage system influences hydrophobicity but not water repellency of a clay loam soil in southwestern Ontario. Canadian Journal of Soil Science, 99, 575-578. https://doi.org/10. 1139/cjss-2019-0051

Nokken, M. R., \& Hooton, R. D. (2008). Using pore parameters to estimate permeability or conductivity of concrete. Materials and Structures/Materiaux et Constructions, 41, 1-16. https://doi.org/10. 1617/s11527-006-9212-y

Nyman, P., Sheridan, G., \& Lane, P. N. J. (2010). Synergistic effects of water repellency and macropore flow on the hydraulic conductivity of a burned forest soil, South-East Australia. Hydrological Processes, 24 2871-2887. https://doi.org/10.1002/hyp.7701

Otsu, N. (1979). A threshold selection method from gray-level histograms. IEEE Transactions on Systems, Man, and Cybernetics, 9, 62-66. https:// doi.org/10.1109/tsmc.1979.4310076

Pagliai, M., Vignozzi, N., \& Pellegrini, S. (2004). Soil structure and the effect of management practices. Soil and Tillage Research, 79, 131-143. https://doi.org/10.1016/j.still.2004.07.002

Palm, C., Blanco-Canqui, H., DeClerck, F., Gatere, L., \& Grace, P. (2014). Conservation agriculture and ecosystem services: An overview. Agriculture, Ecosystems and Environment, 187, 87-105. https://doi.org/10. 1016/j.agee.2013.10.010

Parvin, N., Beckers, E., Plougonven, E., Léonard, A., \& Degré, A. (2017). Dynamic of soil drying close to saturation: What can we learn from a comparison between X-ray computed microtomography and the evaporation method ? Geoderma, 302, 66-75. https://doi.org/10.1016/j. geoderma.2017.04.027

Pittelkow, C. M., Liang, X., Linquist, B. A., Van Groenigen, L. J., Lee, J., Lundy, M. E., ... Van Kessel, C. (2015). Productivity limits and potentials of the principles of conservation agriculture. Nature, 517, 365-368. https://doi.org/10.1038/nature13809

Pituello, C., Dal Ferro, N., Simonetti, G., Berti, A., \& Morari, F. (2016). Nano to macro pore structure changes induced by long-term residue management in three different soils. Agriculture, Ecosystems and Environment, 217, 49-58. https://doi.org/10.1016/j.agee.2015.10.029

Plaza-Álvarez, P. A., Lucas-Borja, M. E., Sagra, J., Moya, D., AlfaroSánchez, R., González-Romero, J., \& De las Heras, J. (2018). Changes in soil water repellency after prescribed burnings in three different Mediterranean forest ecosystems. Science of the Total Environment, 644, 247-255. https://doi.org/10.1016/j.scitotenv.2018.06.364

Rabot, E., Wiesmeier, M., Schlüter, S., \& Vogel, H. J. (2018). Soil structure as an indicator of soil functions: A review. Geoderma, 314, 122-137. https://doi.org/10.1016/j.geoderma.2017.11.009 
Renard, P., \& Allard, D. (2013). Connectivity metrics for subsurface flow and transport. Advances in Water Resources, 51, 168-196. https://doi. org/10.1016/j.advwatres.2011.12.001

Ritsema, C. J., Dekker, L. W., Oostindie, K., Moore, D., Leinauer, B., \& Logsdon, S. (2008). Soil water repellency and critical soil water content. In Soil science: Step by step field analysis (pp. 97-112). Washington, DC: ASA-CSSA-SSSA.

Roper, M. M., Ward, P. R., Keulen, A. F., \& Hill, J. R. (2013). Under notillage and stubble retention, soil water content and crop growth are poorly related to soil water repellency. Soil and Tillage Research, 126, 143-150. https://doi.org/10.1016/j.still.2012.09.006

Rye, C. F., \& Smettem, K. R. J. (2017). The effect of water repellent soil surface layers on preferential flow and bare soil evaporation. Geoderma, 289, 142-149. https://doi.org/10.1016/j.geoderma.2016.11.032

Sandin, M., Koestel, J., Jarvis, N., \& Larsbo, M. (2017). Post-tillage evolution of structural pore space and saturated and near-saturated hydraulic conductivity in a clay loam soil. Soil \& Tillage Research, 165, 161-168. https://doi.org/10.1016/j.still.2016.08.004

Schlüter, S., Albrecht, L., Schwärzel, K., \& Kreiselmeier, J. (2020). Longterm effects of conventional tillage and no-tillage on saturated and near-saturated hydraulic conductivity-Can their prediction be improved by pore metrics obtained with X-ray CT? Geoderma, 361, 114082. https://doi.org/10.1016/j.geoderma.2019.114082

Schlüter, S., \& Vogel, H.-J. (2011). On the reconstruction of structural and functional properties in random heterogeneous media. Advances in Water Resources, 34, 314-325. https://doi.org/10.1016/J. ADVWATRES.2010.12.004

Schmidt, M. W. I., Torn, M. S., Abiven, S., Dittmar, T., Guggenberger, G., Janssens, I. A., ... Trumbore, S. E. (2011). Persistence of soil organic matter as an ecosystem property. Nature, 478, 49-56. https://doi.org/ 10.1038/nature10386

Seaton, F. M., Jones, D. L., Creer, S., George, P. B. L., Smart, S. M., Lebron, I., ... Robinson, D. A. (2019). Plant and soil communities are associated with the response of soil water repellency to environmental stress. Science of the Total Environment, 687, 929-938. https://doi. org/10.1016/j.scitotenv.2019.06.052

Skaggs, T. H. (2006). Percolation theory for flow in porous media (Lecture Notes in Physics 674). Vadose Zone Journal, 5, 1154. https://doi.org/ $10.2136 / v z j 2006.0046 \mathrm{br}$

Smet, S., Beckers, E., Plougonven, E., Léonard, A., \& Jarvis, N. (2018). Can the pore scale geometry explain soil sample scale hydrodynamic properties ? Frontiers in Environmental Science, 6, 20. https://doi.org/10. 3389/fenvs.2018.00020

Sparling, G. P. (1992). Ratio of microbial biomass carbon to soil organic carbon as a sensitive indicator of changes in soil organic matter. Australian Journal of Soil Research, 30, 195-207. https://doi.org/10. 1071/SR9920195

Stavi, I., Barkai, D., Knoll, Y. M., \& Zaady, E. (2016). Livestock grazing impact on soil wettability and erosion risk in post-fire agricultural lands. Science of the Total Environment, 573, 1203-1208. https://doi. org/10.1016/j.scitotenv.2016.03.126

Stockmann, U., Adams, M. A., Crawford, J. W., Field, D. J., Henakaarchchi, N., Jenkins, M., ... Zimmermann, M. (2013). The knowns, known unknowns and unknowns of sequestration of soil organic carbon. Agriculture, Ecosystems \& Environment, 164, 80-99. https://doi.org/10.1016/J.AGEE.2012.10.001

Tadayonnejad, M., Mosaddeghi, M. R., \& Ghorbani, S. (2017). Changing soil hydraulic properties and water repellency in a pomegranate orchard irrigated with saline water by applying polyacrylamide. Agricultural Water Management, 188, 12-20. https://doi.org/10.1016/j.agwat. 2017.03.026
Tillman, R. W., Scotter, D. R., Wallis, M. G., \& Clothier, B. E. (1989). Water repellency and its measurement by using intrinsic sorptivity. Soil Research, 27, 637-644. https://doi.org/10.1071/SR9890637

Urbanek, E., Hallett, P., Feeney, D., \& Horn, R. (2007). Water repellency and distribution of hydrophilic and hydrophobic compounds in soil aggregates from different tillage systems. Geoderma, 140, 147-155. https://doi.org/10.1016/J.GEODERMA.2007.04.001

Vance, E. D., Brookes, P. C., \& Jenkinson, D. S. (1987). An extraction method for measuring soil microbial biomass $\mathrm{C}$. Soil Biology and Biochemistry, 19, 703-707. https://doi.org/10.1016/0038-0717(87) 90052-6

Wander, M. (2004). Soil organic matter fractions and their relevance to soil function. In Soil organic matter in sustainable agriculture (pp. 67-102). Boca Raton, FL: CRC Press.

Wang, B., Gao, L., Yu, W., Wei, X., Li, J., Li, S., ... Wu, X. (2019). Distribution of soil aggregates and organic carbon in deep soil under long-term conservation tillage with residual retention in dryland. Journal of Arid Land, 11, 241-254. https://doi.org/10.1007/s40333-019-0094-6

Weninger, T., Filipovi, V., Me, M., Clothier, B., \& Filipovi, L. (2019). Estimating the extent of fire induced soil water repellency in Mediterranean environment. Geoderma, 338, 187-196. https://doi.org/10.1016/j. geoderma.2018.12.008

Woche, S. K., Goebel, M. O., Kirkham, M. B., Horton, R., Van Der Ploeg, R. R., \& Bachmann, J. (2005). Contact angle of soils as affected by depth, texture, and land management. European Journal of Soil Science, 56, 239-251. https://doi.org/10.1111/j.1365-2389.2004. 00664.x

Xiong, Y., Furman, A., \& Wallach, R. (2012). Moment analysis description of wetting and redistribution plumes in wettable and water-repellent soils. Journal of Hydrology, 422-423, 30-42. https://doi.org/10.1016/ j.jhydrol.2011.12.010

Young, I. M., Crawford, J. W., \& Rappoldt, C. (2001). New methods and models for characterising structural heterogeneity of soil. Soil and Tillage Research, 61, 33-45. https://doi.org/10.1016/S0167-1987(01) 00188-X

Zavala, L. M., González, F. A., \& Jordán, A. (2009). Intensity and persistence of water repellency in relation to vegetation types and soil parameters in Mediterranean SW Spain. Geoderma, 152, 361-374. https://doi. org/10.1016/j.geoderma.2009.07.011

Zhang, B., Yao, S. H., \& Hu, F. (2007). Microbial biomass dynamics and soil wettability as affected by the intensity and frequency of wetting and drying during straw decomposition. European Journal of Soil Science, 58, 1482-1492. https://doi.org/10.1111/j.1365-2389.2007.00952.x

Zhang, J., Wang, Y., Liu, J., Liu, Q., \& Zhou, Q. (2016). Multivariate and geostatistical analyses of the sources and spatial distribution of heavy metals in agricultural soil in Gongzhuling, Northeast China. Journal of Soils and Sediments, 16, 634-644. https://doi.org/10.1007/s11368015-1225-0

Zheng, W., Morris, E. K., Lehmann, A., \& Rillig, M. C. (2016). Interplay of soil water repellency, soil aggregation and organic carbon. A metaanalysis. Geoderma, 283, 39-47. https://doi.org/10.1016/j.geoderma. 2016.07.025

How to cite this article: Li S, Lu J, Liang G, et al. Factors governing soil water repellency under tillage management: The role of pore structure and hydrophobic substances. Land Degrad Dev. 2021;32:1046-1059. https://doi.org/10.1002/ $\underline{\text { Idr.3779 }}$ 